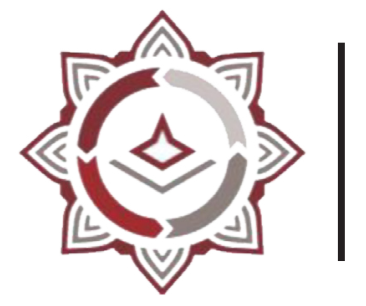

BISNIS: Jurnal Bisnis dan Manajemen Islam

P-ISSN: 2442-3718, E-ISSN: 2477-5533

Volume 9, Nomor 1, Juni 2021 (PP : 1-16)

https://journal.iainkudus.ac.id/index.php/Bisnis/index

http://dx.doi.org/10.21043/bisnis.v9i1.10132

\title{
Studi Independensi DPS Perbankan Syariah Indonesia
}

\author{
Zata Atikah Amani' ${ }^{1}$, Rifqi Muhammad ${ }^{2}$ \\ Universitas Gadjah Mada ${ }^{1}$, Universitas Islam Indonesia ${ }^{2}$ \\ zata.a.a@mail.ugm.ac.id ${ }^{1}$,rifqimuhammad@uii.ac.id ${ }^{2}$
}

\begin{abstract}
This paper aims to evaluate the independence of the Sharia Supervisory Board (DPS) in the Islamic banking sector in Indonesia. This paper departs from the background that the sharia supervisory function is important to ensure that Sharia Financial Institutions (LKS) have carried out their operational activities in accordance with sharia principles. DPS is a representation of the National Sharia Council (DSN) Indonesian Ulema Council (MUI) assigned to each LKS to ensure that sharia compliance can be carried out properly. However, the limited number of DPS resulted in an irony where members of the DSN-MUI were often members of DPS and even became members of DPS in several LKS. This makes the issue of independence interesting to discuss, especially in relation to the optimization and effectiveness of the sharia supervisory function. This paper uses the approach of Islamic agency theory and sharia governance to evaluate the independence of SSB, especially in Indonesian Islamic banking to provide recommendations for the possibility of improving the role of SSB and its governance in the organizational structure of Islamic banking in Indonesia.
\end{abstract}

Keywords: Independence, Sharia Supervisory Board (DPS), Islamic banking, Islamic agency theory, Sharia governance.

\begin{abstract}
Abstrak
Paper ini bertujuan untuk mengevaluasi independensi Dewan Pengawas Syariah (DPS) pada sektor perbankan syariah di Indonesia. Paper ini berangkat dari latar belakang bahwa fungsi pengawasan syariah merupakan hal penting untuk menjamin bahwa Lembaga Keuangan Syariah (LKS) telah menjalankan kegiatan operasionalnya sesuai dengan prinsip syariah. DPS merupakan representasi dari Dewan Syariah Nasional (DSN) Mejelis Ulama Indonesia (MUI) yang ditempatkan pada masing-masing LKS untuk menjamin kepatuhan syariah dapat dijalankan dengan baik. Namun demikian, jumlah DPS yang terbatas mengakibatkan adanya ironi dimana anggota DSN-MUI tidak jarang juga merupakan anggota DPS dan bahkan menjadi anggota DPS di beberapa LKS. Hal ini menjadikan isu independensi menjadi menarik
\end{abstract}


untuk dibahas khususnya terkait dengan optimalisasi dan efektivitas fungsi pengawasan syariah. Paper ini menggunakan pendekatan teori keagenan Islam dan shariah governance untuk mengevaluasi independensi DPS khususnya di perbankan syariah Indonesia untuk memberikan rekomendasi adanya kemungkinan perbaikan peran DPS dan tata kelolanya dalam struktur organisasi perbankan syariah di Indonesia.

Kata Kunci: Independensi, Dewan Pengawas Syariah (DPS), Perbankan syariah, teori keagenan Islam, Shariah governance.

\section{PENDAHULUAN}

Lembaga keuangan syariah (LKS) di Indonesia menunjukkan perkembangan yang cukup pesat terutama bank Syariah sejak terjadinya krisis moneter pada tahun 1997 yang berdampak pada likuiditas perbankan konvensional. Hal tersebut dibuktikan dengan dukungan dari pemerintahan pusat terhadap LKS yang sudah diatur di dalam Undang-Undang. Berbagai Undang-Undang yang mendukung tentang sistem lembaga keuangan Syariah seperti Undang-Undang Nomor 7 Tahun 1992 tentang Perbankan yang sebagaimana telah diubah dalam Undang-Undang Nomor 10 tahun 1998 dan Undang-Undang Nomor 23 Tahun 1999 tentang Bank Indonesia. Bahkan pada tahun 2008 pemerintah akhirnya memberikan kepastian hukum yang lebih kuat dengan adanya UU Nomor 21 tahun 2008 tentang Perbankan Syariah.

Sistem pengawasan terhadap bank Syariah yang tidak hanya terdapat audit internal serta audit eksternal, akan tetapi juga terdapat pengawasan terhadap kepatuhan syariah yang dilakukan oleh DPS yang ditetapkan melalui Rapat Umum Pemegang Saham (RUPS) atas rekomendasi dari Dewan Syariah Nasional (DSN) Majelis Ulama Indonesia (MUI). Sementara itu, posisi DPS dalam struktur organisasi bank syariah merupakan bagian dari pengurus bank syariah tersebut yang akhirnya menjadi salah satu pembeda antara LKS dan lembaga keuangan konvensional.

DPS, selaku wakil DSN-MUI, berperan mengawasi kegiatan operasional yang dijalankan oleh bank syariah sesuai dengan fatwa-fatwa yang telah dikeluarkan oleh DSN MUI. Meskipun sudah lebih dari satu dekade ini perbankan syariah tumbuh dan berkembang pesat di Indonesia, akan tetapi tidak menjamin bahwa perbankan syariah telah terbebas dari kegiatan yang menyimpang dari kepatuhan syariah. Hal itu terjadi dikarenakan produk-produk dari perbankan syariah akan terus berinovasi sehingga diperlukannya pengawasan dari DPS. Jika nantinya masih belum adanya 
fatwa yang mencakup dari produk yang dikeluarkan oleh perbankan Syariah, hal tersebut akan menjadi tugas DPS yang akan menyampaikan kepada pihak DSN MUI untuk dibuatkan fatwa sesuai hukum Syariah yang berlaku.

Independensi DPS sering kali dipertanyakan karena DPS diperbolehkan untuk rangkap jabatan sebagai DPS di beberapa LKS lainnya, selain itu DPS juga diperbolehkan untuk menjadi anggota DSN MUI. Jika di dalam pengawasan laporan keuangan yang dilakukan oleh pihak internal yaitu auditor internal perusahaan dan pengawasan laporan keuangan tahunan yang dilakukan oleh akuntan publik sebagai auditor eksternal merupakan pihak yang berbeda dan biasanya setiap tahunnya auditor eksternal yang mengaudit laporan keuangan perusahaan akan berbeda untuk menghindari conflict of interest antara pihak perusahaan dengan auditor eksternal.

Teori keagenan Islam yang menjelaskan mengenai bagaimana Islam memandang dengan adanya pengawasan yang dilakukan oleh pihak lain sebagai agen yang memberikan layanan atas nama orang lain dari perusahaan tersebut. Hal tersebut diperbolehkan dengan adanya akad yang bernama wakalah. Teori ini dapat menjelaskan bagaimana independensi DPS sebagai auditor kepatuhan syariah pada bank syariah.

\section{KAJIAN LITERATUR}

\section{Audit dari Sudut Pandang Islam}

Menurut Kamus Besar Bahasa Indonesia (KBBI), audit adalah pemeriksaan pembukuan tentang keuangan (perusahaan, bank, dan sebagainya) secara berkala. Sedangakan menurut Mulyadi dan Kanaka Puradiredja di dalam Fauzi \& Supandi (2019) mendefinisikan auditing sebagai proses sistematis untuk mempelajari dan mengevaluasi bukti secara objektif mengenai pernyataan-pernyataan tentang kegiatan dan kejadian ekonomi untuk menetapkan tingkat kesesuaian antara pernyataan tersebut dan kriteria yang telah ditetapkan, serta penyampaian hasilhasilnya kepada pemakai yang berkepentingan.

Accounting and Auditing Organization for Islamic Financial Institutions (AAOIFI) merupakan organisasi yang mengeluarkan standar audit Syariah yang berlaku pada keuangan Syariah. Auditing Standard for Islamic Financial Institutions (ASIFI) atau Standar Audit untuk Lembaga Keuangan Syariah (AAOIFI, 2017) menyatakan 
bahwa tujuan audit atas laporan keuangan Lembaga Keuangan Syariah adalah untuk memberikan keyakinan atau jaminan di mana suatu kegiatan penilaian untuk meningkatkan kepercayaan pengguna yang akan dituju. Suatu audit atas laporan keuangan melibatkan pemeriksaan atas laporan keuangan dengan tujuan untuk menyatakan berupa opini bahwa laporan keuangan tersebut terbebas dari salah saji material. Sehingga dapat disimpulkan bahwa audit dalam Islam merupakan bentuk ikhtiar atau usaha dalam menkonfirmasi suatu pernyataan dengan menunjuk suatu wakil yang bertugas sebagai pihak independen yang memberikan suatu opini berdasarkan bukti-bukti yang diberikan.

Landasan dari pelaksanaan audit Syariah dapat ditunjuk pada QS Al Hujurat (49) ayat 6 yang artinya:

"Wahai orang-orang yang beriman! Jika seseorang yang fasik datang kepadamu membawa suatu berita, maka telitilah kebenarannya, agar kamu tidak mencelakakan suatu kaum karena kebodohan (kecerobohan), yang akhirnya kamu menyesali perbuatan itu"

Ayat tersebut menunjukkan bahwa pentingnya untuk memeriksa secara teliti terhadap bukti atau informasi sebelum bukti atau informasi tersebut disebarkan kepada pihak lain agar bukti atau informasi tersebut tidak menyesatkan atau menjadi penyebab terjadinya musibah dikemudiannya.

\section{Kepatuhan Syariah}

Menurut Muhammad Syafei Antonio di dalam Wardayati (2011) sharia compliance atau kepatuhan Syariah adalah ketaatan bank syariah terhadap prinsipprinsip syariah. Bank syariah merupakan lembaga keuangan yang beroperasi sesuai dengan prinsip-prinsip syariah atau hukum Islam yang artinya bank dalam beroperasinya mengikuti ketentuan-ketentuan syariah atau hukum Islam khususnya menyangkut tata cara bermuamalat secara Islam. Prinsip utama bank Syariah tercermin dalam jenis produk-produk yang ditawarkan yang di mana terbebas dari bunga dan digantikan dengan sistem bagi hasil.

Regulasi kepatuhan Syariah untuk perbankan Syariah telah diatur di dalam amandemen Undang-Undang Nomor 7 Tahun 1992 yang diubah pada Undang-Undang Nomor 10 Tahun 1998 tentang Perbankan sebagai bentuk awal beroperasinya perbankan syariah di Indonesia. Semakin berkembangnya perbankan 
Syariah di Indonesia, sehingga dibutuhkannya peraturan guna untuk menguatkan sistem berjalannya perbankan syariah di Indonesia. Menurut Nurhisam (2016) dikarenakan masih lemahnya peraturan yang ada di dalam Undang-Undang tersebut, sehingga dikeluarkannya aturan dari Bank Indonesia dalam bentuk Peraturan Bank Indonesia (PBI) dan Surat Edaran Bank Indonesia (SEBI). Diterbitkannya Peraturan Bank Indonesia (PBI) Nomor 7/35/PBI/2005 tentang Perubahan Atas Peraturan Bank Indonesia Nomor 6/24/PBI/2004 tentang Bank Umum yang Melaksanakan Kegiatan Usaha Berdasarkan Prinsip Syariah, serta PBI Nomor 8/3/PBI/2006 tentang Perubahan Kegiatan Usaha Bank Umum Konvensional Menjadi Bank Umum yang Melaksanakan Kegiatan Usaha Berdasarkan Prinsip Syariah dan Pembukaan Kantor Bank yang Melaksanakan Kegiatan Usaha Berdasarkan Prinsip Syariah oleh Bank Umum Konvensional. Sehingga, sehubungan dengan regulasi sebelumnya, maka diterbitkan Undang-undang Nomor 21 Tahun 2008 tentang Perbankan Syariah yang lebih tegas dan terintergrasi dalam mengatur perbankan Syariah yang ada di Indonesia.

\section{Independensi pada Audit Kepatuhan Syariah}

Menurut Abdel Karim (1990), terdapat kesamaan sifat dan peran antara Dewan Pengawas Syariah (DPS) dengan auditor eksternal. DPS serta auditor eksternal menerbitkan laporan dan memverifikasi bahwa laporan keuangan yang diterbitkan oleh manajemen bank Syariah mewakili jalannya perusahaan secara wajar. DPS menyatakan bahwa aktivitas bank sebagaimana yang tercermin dalam laporan keuangan sesuai dengan kepatuhan Syariah. DPS harus dianggap independen oleh pengguna laporan agar laporan kredibilitas laporan yang diterbitkan tidak mendapatkan keraguan.

Menurut Noviaty dan Kusuma (2001) di dalam Prasetyoningrum (2010) menyatakan bahwa independensi akuntan publik mencakup dua aspek yaitu independensi fakta (fact) dan independensi penampilan (appearance). Independensi fakta berarti adanya kejujuran di dalam diri akuntan dalam mempertimbangkan fakta-fakta dan adanya pertimbangan yang obyektif, tidak memihak di dalam merumuskan dam menyatakan pendapatnya. Sedangkan independensi penampilan berarti adanya kesan masyarakat bahwa akuntan public bertindak independent sehingga akuntan piblik harus menghindari keadaan atau faktor-faktor yang dapat mengakibatkan masyarakat meragukan independensinya. Dalam hal ini, DPS dituntun untuk bersikap independen baik secara fakta maupun penampilan. 
Abdel Karim (1990) yang juga manyatakan bahwa sifat independensi DPS memfokuskan pada kesetiaan terhadap institusi pada ajaran Islam untuk terus komitmen pada prinsip-prinsip bisnis yang Islami atau sesuai dengan kepatuhan Syariah, sehingga diharapkan tidak tergantung pada tekanan dari manajemen perusahaan. Kesanggupan untuk nilai-nilai religius dan kewajiban religius merangsang anggota DPS untuk independent. Pada sisi lain, tidak berarti bahwa ketegangan antara manajemen perusahaan dan DPS tidak mungkin ada. Hal tersebut bisa saja terjadi jika manajemen perusahaan cenderung untuk memberi penekanan lebih dari aspek finansial ekonomi dibandingkan dengan aspek religiusitas.

\section{Teori Keagenan dalam Perspektif Islam}

Menurut Anggraeni (2011), agency theory atau teori keagenan timbul sebagai akibat adanya dua pihak atau dua individu di dalam organisasi yang bertentangan terhadap kepentingan masing-masing, di mana kedua individu tersebut memiliki tujuan untuk memaksimalkan tingkat kepuasannya masing-masing atau utilitas. Di dalam agency theory timbul adanya informasi asimetris yang merupakan suatu kondisi di mana beberapa pihak yang terkait memiliki informasi lebih banyak daripada pihak lainnya.

Istilah wakalah atau wikalah merupakan kata benda yang berasal dari kata wakala yang memiliki beberapa arti, termasuk melakukan suatu tugas atas nama orang lain atau menjadi wakil. Secara teknis wakalah mengacu pada kontrak yang di mana seorang muwakkil (pihak utama) memberikan wewenang kepada salah satu pihak sebagai wakil (agen) untuk melakukan tugas atasnamanya (Khalid \& Sarea, 2020). Menurut AAOIFI (2017), wakalah adalah tindakan dari satu pihak yang mendelegasikan yang lain untuk bertindak atas Namanya dalam apa yang dapat menjadi pokok bahasan pendelegasian. Allah berfirman pada QS An-Nisa (4) ayat 35 yang artinya: "Dan jika kamu khawatir terjadi persengketaan antara keduanya, maka kirimlah seorang juru damai dari keluarga laki-laki dan seorang juru damai dari keluarga perempuan..." serta di dalam QS At-Taubah ayat 60 yang artinya: "Sesungguhnya zakat itu hanyalah untuk orang-orang fakir, orang miskin, amil zakat (pengelola zakat).... Secara umum, ayat-ayat tersebut menunjukkan bahwa Islam memperbolehkan pihak ketiga diantara pemilik dana dengan penerima dana yang ditunjut sebagai wasit atau agen untuk mengelola dan menjalankan zakat tersebut. 
Konsep khalifah (wakil) dan Ihsan berpengaruh positif pada hubungan yang diatur oleh teori keagenan Islam. Sejalan dengan konsep khilafah, akuntanbilitas lebih menekankan pada kewajiban daripada hak karena jika kewajiban dipenuhi oleh semua orang, kepentingan pribadi secara otomatis berada dalam batas-batas dan hak semua tidak diragukan lagi dilindungi (Chapra, 1992 pada Khalid \& Sarea, 2020).

Ketidakseimbangan informasi memperburuk masalah keagenan, di mana pihak utama tidak dapat mengakses secara keseluruhan informasi agen. Namun asimetris informasi tidak diperoleh ketika kedua belah pihak terlibat dalam hubungan dengan Allah. Seorang agen (wakil) memahami bahwa mereka memiliki kewajiban untuk memenuhi kewajiban kepada pihak utama (muwakkil). Kedua belah pihak percaya bahwa Allah memiliki ilmu yang sempurna adan atas segala perbuatan mereka akan dipertanggungjawabkan di akhirat kelak (Khalid \& Sarea, 2020). Oleh karena itu, setiap tindakan dan keputusan mereka harus selaras dengan kewajiban yang dengan setia dijalankan sebagaimana yang tertuang di dalam kontrak keagenan mereka (Shamsuddin \& Ismail, 2013)

\section{METODE PENELITIAN}

Pembahasan paper ini menggunakan pendekatan deskriptif kualitatif dengan menggunakan beberapa sumber referensi yang relevan terkait dengan peran dan fungsi DPS, antara lain: pertama, paper-paper jurnal nasional dan internasonal yang membahas peran dan kontribusi DPS pada industri keuangan syariah baik di level nasional maupun internasional. Kedua, undang-undang perbankan syariah dan peraturan regulator melalui OJK serta Bank Indonesia. Ketiga, fatwa DSN MUI, surat edaran, maupun bahan sosialisasi tentang peran DPS diperbankan syariah. Keempat, buku ilmiah dan publikasi informasi melalui website bank syariah. Selanjutnya, bahan-bahan literatur tersebut akan ditelaah serta dilakukan pemetaan dalam mendapat informasi yang relevan terkait fakta obyektif sebagai bahan evaluasi independensi DPS di perbankan syariah Indonesia. 


\section{HASIL DAN PEMBAHASAN}

\section{Kedudukan dan Peran DSN-MUI dan DPS dalam Menjalankan Fungsi Pengawasan Syariah}

Berdasarkan Peraturan Otoritas Jasa Keuangan (OJK) Nomor 3 Tahun 2014, tingkat pengawasan pertama dinamakan Dewan Pengawas Syariah (DPS) sedangkan pengawasan tingkat nasional terdapat Dewan Syariah Nasional (DSN). DPS adalah bagian dari organ entitas bank syariah yang mempunyai tugas dan fungsi pengawasan terhadap penyelenggaraan kegiatan perusahaan agar sesuai dengan prinsip Syariah. DPS merupakan seorang ahli syariah atau lebih yang diangkat oleh Rapat Umum Pemegang Saham (RUPS) atas rekomendasi Dewan Syariah Nasional (DSN). DSN merupakan bagian dari Majelis Ulama Indonesia (MUI) yang merupakan lembaga independen yang mewadahi para ulama dan cendekiawan Islam untuk membimbing, membina, dan mengayomi umat Islam di Indonesia (www.mui.or.id). MUI memiliki otoritas dalam mengeluarkan fatwa terkait dengan masalah-masalah muamalah.

DSN MUI terdiri dari para pakar dengan latar belakang disiplin keilmuan ekonomi dan fikih Islam, serta praktisi dari LKS dan perwakilan regulator dengan masa bakti selama lima tahun. DSN MUI memiliki tugas yaitu menetapkan fatwa atas sistem, kegiatan, produk, dan jasa lembaga keuangan syariah serta mengawasi penerapan fatwa melalui DPS yang ditunjuk di lembaga keuangan Syariah tertentu. DSN MUI juga memiliki wewenang yaitu memberikan peringatan kepada lembaga keuangan syariah untuk menghentikan penyimpangan dari fatwa yang diterbitkan oleh DSN MUI serta merekomendasikan kepada pihak yang berwenang untuk mengambil tindakan apabila peringatan tidak diindahkan (www.dsnmui.or.id).

Untuk menjalankan tugas dan wewenang, DSN MUI merekomendasikan seorang atau cendekiawan muslim untuk menjadi Dewan Pengawas Syariah (DPS). menurut Surat Edaran Bank Indonesia Nomor 8/19/DPbs, DPS memiliki tugas, wewenang, dan tanggung jawab antara lain memastikan dan mengawasi kesesuaian kegiatan operasional bank terhadap fatwa yang dikeluarkan oleh DSN, menilai aspek syariah terhadap pedoman operasional dan produk yang dikeluarkan bank, memberikan opini dari aspek syariah terhadap pelaksanaan operasional bank secara keseluruhan dalam laporan publikasi bank, mengkaji produk dan jasa baru yang belum ada fatwa untuk dimintakan fatwa kepada DSN, dan menyampaikan laporan hasil pengawasan syariah. 
Dari hasil penelitian dari Khotibul (2015) di dalam Nurhisam (2016), bahwa diperlukan sikap profesional yang harus dimiliki oleh seorang DPS dalam melaksanakan tugas serta wewenangnya sebagai pengawas industri keuangan syariah yang sedikitnya ada lima prinsip minimal yang harus dirumuskan dalam penyusunan standar etik professional diantara lain: pertama, bertanggung jawab. DPS harus melaksanakan tugas dan wewenangnya dengan sebaik-sebaiknya, sebagai bentuk tanggung jawabnya menjadi pengawas dalam kepatuhan Syariah dalam menjaga masyarajat terhadap profesionalitas sebagai DPS. Kedua, Integritas tinggi. Dalam melaksanakan tugas, DPS harus jujur dan setia terhadap nilai dan norma yang berlaku, baik dari segi hukum positif maupun normatif (syariah) agar dapat mempertahankan kepercayaan masyarakat. Ketiga, independensi. Seorang DPS harus bersikap obyektif, bebas dari intervensi dari siapapun, serta bebas dari segala pertentangan kepentingan dalam melaksanakan tugas dan wewenang sebagai pengawas dalam industri keuangan syariah. Keempat, kecermatan. DPS selalu memperhatikan standar teknis dan standar etika dalam melaksanakan tugasnya dan membuka diri untuk terus belajar dalam meningkatkan kualitas kompetensi diri sebagai DPS yang memiliki sifat profesionalisme. Kelima, bersikap profesional. DPS harus bersungguh-sungguh dalam melaksanakan tugas dan wewenangnya yang didukung dengan pengetahuan, keterampilan dan wawasan yang sangat luas sehingga dapat menyelesaikan setiap permasalahan seperti konflik yang ada dengan efektif dan efisien.

Gambar 1 di bawah ini memberikan penjelasan mengenai struktur organisasi bank syariah dimana posisi DPS yang ditunjuk melalui RUPS dan sejajar dengan dewan komisaris. Walaupun sejajar posisinya, namun dalam fungsi dan perannya masing-masing berbeda karena dewan komisaris fokus pada aspek bisnis dan pengembangan usaha, sementara DPS memiliki fokus dalam aspek pengawasan syariah dalam semua kegiatan operasionalnya. Bersama direksi, DPS dan dewan komisaris menjalankan kegiatan operasional bank syariah serta memastikan bahwa bank syariah selalu tunduk dan patuh pada ketentuan syariah dengan tetap berupaya mengembangkan usahanya secara profesional. 


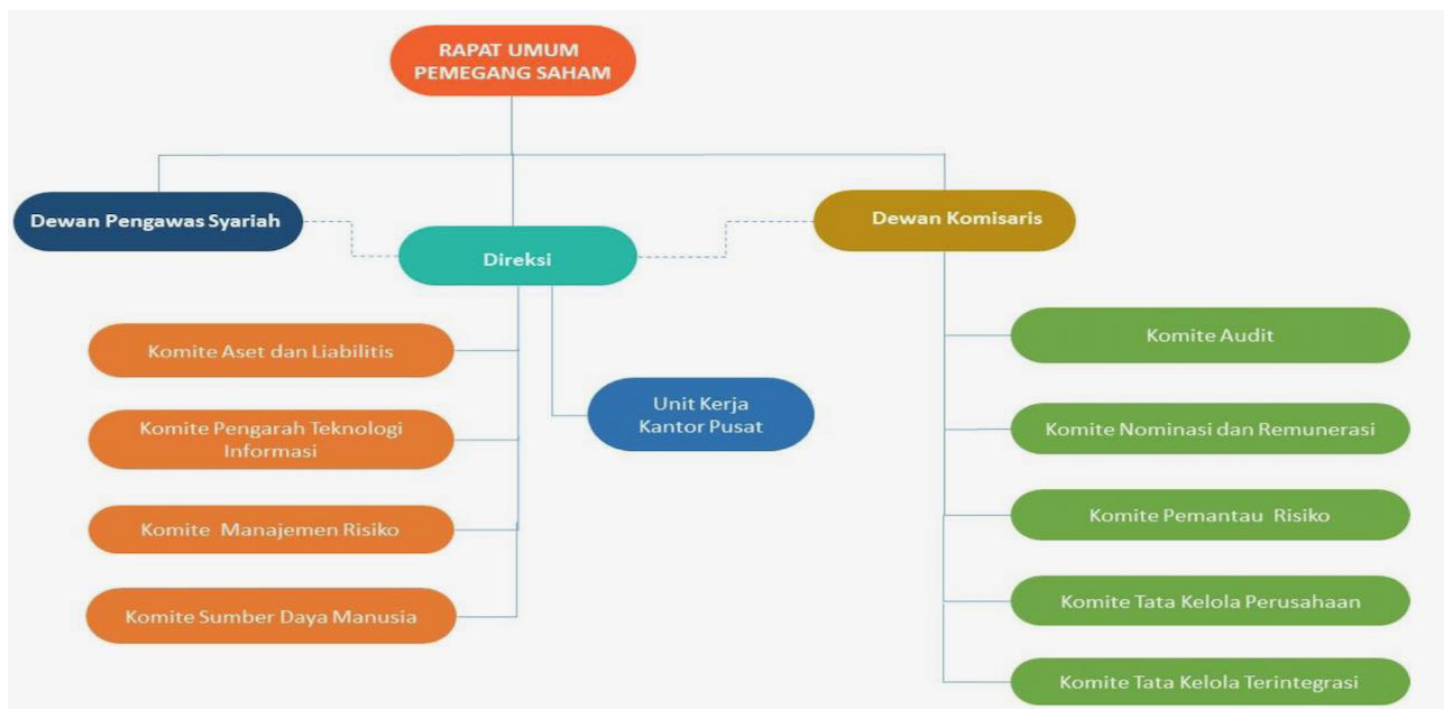

Gambar 1. Struktur Organisasi Bank Syariah (Bank Muamalat, 2018)

Surat Edaran Bank Indonesia Nomor 12/13/DPbs tentang Pelaksanaan Good Corporate Governance bagi Bank Umum Syariah dan Unit Usaha Syariah, jumlah anggota DPS di bank syariah setidaknya dua orang dan paling banyak setengah dari jumlah Direksi dengan penetapan masa jabatan anggota DPS paling lama sama dengan masa jabatan Direksi atau Dewan Komisaris atau yang dimaksud sama dengan satu periode pengangkatan. Berdasarkan peran DPS menurut Majelis Ulama Indonesia (MUI) dengan Surat Keputusan DSN MUI Nomor 98/MUI/III/2001 tentang susunan Pengurus DSN MUI di dalam penelitian (Munthe et al., 2019), peran DPS dalam mengimplementasikan prinsip-prinsip Good Corporate Governance di bank syariah adalah yaitu pertama sebagai directing yaitu memberikan pengarahan, pemikiran, saran, dan nasehat kepada direksi bank Syariah mengenai hal-hal yang berkaitan dengan aspek syariah. Kedua sebagai reviewing yaitu mencermati, memeriksa, mengkaji, dan menilai implementasi fatwa DSN pada operasional bank syariah. Ketiga sebagai supervising yaitu melaksanakan tugas pengawas baik secara aktif maupun secara pasif atas implementasi fatwa DSN pada operasional bank syariah. Keempat sebagai marketing yaitu melakukan sosialisasi dan edukasi kepada masyarakat tentang bank Syariah melalui media-media yang sudah berjalan di masyarakat, seperti khutbah, majelis ta'lim, dan pengajian-pengajian.

DPS diperbolehkan dalam rangkap jabatan yang sudah diatur di dalam Peraturan Bank Indonesia Nomor 11/10/PBI/2009 tentang Unit Usaha Syariah, 
di mana seorang DPS diperbolehkan untuk rangkap jabatan sebagai DPS sebanyak empat di lembaga keuangan syariah lainnya. Serta, DPS juga diperbolehkan untuk merangkap jabatan sebagai anggota DSN MUI.

\section{Independensi DPS sebagai Auditor Kepatuhan Syariah berdasarkan Teori Keagenan Islam}

Menurut Jesen dan Meckling (1976) di dalam penelitian Khalid dan Sarea (2020) teori keagenan yang merepresentasikan bahwa terdapat kontrak di mana satu atau lebih orang sebagai prinsipal melibatkan orang lain yang di mana sebagai agen untuk melakukan beberapa layanan atas nama mereka yang melibatkan pendelegasian beberapa otoritas pengambilan keputusan kepada agen. DPS merupakan perwakilan atau agen dari DSN MUI yang ditunjuk sebagai pihak untuk mengaudit kepatuhan Syariah pada perbankan Syariah di Indonesia. Peran, tugas, dan wewenang DPS telah dijelaskan di dalam Peraturan Bank Indonesia serta Surat Keputusan yang dikeluarkan oleh MUI.

Masalah keagenan di dalam kasus DPS sebagai auditor kepatuhan Syariah juga merupakan suatu hal yang penting kedudukannya selayaknya auditor internal maupun auditor eksternal. Terdapat beberapa koridor yang perlu diperhatikan sehingga DPS yang memiliki rangkap jabatan di lembaga keuangan Syariah lainnya tidak dipertanyakan independensinya maupun efektivitas dari kinerja DPS ketika ditugaskan pada di lembaga keuangan Syariah tertentu.

Pada proses pengangkatan DPS yang telah dijelaskan pada Peraturan Bank Syariah Nomor 11/10/PBI/2009 tentang Unit Usaha Syariah pada Bagian Kedua Pasal 9, seorang DPS harus memenuhi syarat antara lain:

a. Integritas dengan mencakup:

1. Memiliki akhlak dan moral yang baik

2. Memiliki komitmen untuk mematuhi ketentuan perbankan Syariah dan ketentuan peraturan perundang-undangan lain yang berlaku

3. Memiliki komitmen terhadap pengembangan perbankan Syariah yang sehat dan Tangguh (sustainable), dan

4. Tidak termasuk dalam Daftar Kepatutan dan Kelayakan (Daftar Tidak Lulus) sebagaimana diatur dalam ketentuan mengenai uji kemampuan dan kepatutan (fit dan proper test) yang ditetapkan oleh bank Indonesia 
b. Kompetensi yang dimiliki berupa pengetahuan dan pengalaman yang cukup di bidang Syariah muamalah dan pengetahuan di bidang perbankan atau keuangan secara umum, dan

c. Reputasi keuangan yang mencakup:

1. Tidak masuk dalam daftar kredit macet, dan

2. Tidak pernah dinyatakan pailit atau menjadi pemegang saham, anggota Dewan Komisaris, atau anggota Direksi suatu perseroan dan/atau anggota pengurus suatu badan usaha yang dinyatakan bersalah menyebabkan suatu perseroan dan/atau bandan usaha dinyatakan pailit, dalam waktu 5 (lima) tahun terakhir sebelum dicalonkan.

Ketika DPS telah memenuhi persyaratan yang telah ditentukan pada Peraturan Bank Indonesia, selanjutnya pada Pasal 12 dijelaskan bahwa calon anggota DPS wajib memperoleh persetujuan Bank Indonesia sebelum diangkat dan menduduki jabatannya. Serta, pengajuan calon anggota DPS sebagaimana persetujuan dari Bank Indonesia baru bisa dilakukan setelah mendapatkan rekomendasi dari DSN MUI. Lalu pada Pasal 13 dijelaskan bahwa pengangkatan calon anggota DPS wajib dilaporkan oleh UUS paling lambat sepuluh hari sejak tanggal pengangkatan. Serta pengangkatan calon DPS dilakukan pada saat Rapat Umum Pemegang Saham (RUPS), sehingga jika calon DPS tidak diangkat oleh RUPS dalam jangka waktu tiga bulan yang terhitung sejak tanggal persetujuan diberikan, maka persetujuan terhadap calon anggota DPS tersebut tidak berlaku.

Merujuk pada Surat Keputusan DSN MUI Nomor 3 Tahun 2000 bahwa DPS adalah bagian dari LKS yang bersangkutan yang penempatannya atas persetujuan atau rekomendasi dari DSN MUI. DPS diangkat dan diberhentikan di lembaga keuangan Syariah melalui Rapat Umum Pemegang Saham (RUPS) setelah mendapatkan rekomendasi dari DSN MUI. Meskipun DPS merupakan bagian dari lembaga keuangan syariah, akan tetapi dalam rangka menjamin independensi DPS, menurut Perwataatmadja dan Antonio (1992) di dalam Misbach (2015), hal-hal yang perlu diperhatikan yaitu pertama, anggota DPS bukan staf bank, mereka tidak tunduk di bawah kekuasaan administratif bank. Kedua, mereka dipilih oleh Rapat Umum Pemegang Saham (RUPS). Ketiga, honorarium mereka ditentukan oleh RUPS. Dan keempat, DPS mempunyai sistem kerja dan tugas-tugas tertentu sepeti halnya badan pengawas lainnya. 
Peraturan telah dibuat sedemikian rupa sehingga meminimalisir terjadinya conflict of interest dikarenakan faktor rangkap jabatan dari DPS, akan tetapi celah tersebut masih dapat ditemukan. Dikarenakan Majelis Ulama Indonesia merupakan lembaga independen tidak mendapatkan bantuan dana dari pemerintah sejak tahun 2015, sehingga dana yang didapatkan dari MUI merupakan hasil dari iuran swadaya atau dari jasa yang dilakukan oleh pihak MUI. Jika sumber pendanaan yang didapatkan dari MUI merupakan dari hasil jasa yang diberikan oleh klien tanpa adanya bantuan dana dari pemerintah, sehingga hal tersebut kemungkinan besar akan menjadi conflict of interest antara pihak bank syariah dengan DPS yang merupakan bagian dari LKS akan tetapi juga merupakan anggota dari DSN MUI.

Sementara jika melihat model pengawasan syariah yang dilakukan oleh DPS di Malaysia, maka terdapat dua hal perbedaan penting yang bisa dicatat jika dibandingkan praktik pengawasan DPS di Indonesia. Pertama, posisi DPS tidak boleh merangkap jabatan dengan kepengurusan atau keanggotaan di National Shariah Board (seperti DSN MUI di Indonesia). Namun demikian, National Shariah Board di Malaysia mendapatkan dukungan pendanaan operasional dari pemerintah melalui Bank Negara Malaysia. Sehingga fatwa yang dikeluarkan secara oromatis merupakan bagian regulasi dari Bank Negara Malaysia. Kedua, posisi DPS di suatu bank syariah tidak boleh dirangkap dengan posisi DPS di bank syariah yang lain. Hal ini tertentu berbeda dengan posisi DPS di Indonesia yang masih banyak DPS menjadi bagian dari DSN MUI yang secara fungsinya seharusnya DSN mengawasi DPS. Hal lain adalah sumber dana DSN MUI masih bersifat swadaya di antara LKS-LKS di Indonesia dengan ketentuan tertentu untuk menjaga kelangsungan kelembagaan DSN MUI.

Sejak awal, Islam menekankan pentingnya hubungan antara manusia dengan Allah maupun manusia dengan manusia. Terutama bagi umat Islam, harus dimulai dengan hubungan antara manusia dengan Allah. Semua kegiatan yang ada di bumi akan diminta pertanggung jawabannya kelak. Terlebih lagi DPS sebagai seorang agen yang di mana bertanggung jawab terhadap hasil audit kepatuhan syariah terhadap berjalannya operasional atau muamalah yang berjalan pada LKS. Meskipun tidak keseluruhan nasabah lembaga keuangan Syariah semata-mata hanyalah untuk alasan religius atau agama, akan tetapi beberapa diantaranya berharap bahwa LKS berbeda daripada lembaga keuangan konvensional yang di mana berbasis bunga. 
Tidak hanya hubungan penting dengan pihak inti perusahaan yang di mana antara DPS dengan pihak LKS dan nasabah saja, akan tetapi ada hubungan dengan pihak lainnya seperti penyedia modal, mitra maupun pihak penerima manfaat lainnya. Semuanya memiliki tujuan yang sama yaitu menjalankan amanah yang telah diberikan oleh Allah sesuai dengan hukum-hukum muamalah yang berlaku. Seperti yang tertera pada QS Al Imran ayat 173 yang artinya “...Cukuplah Allah (menjadi penolong) bagi kami dan Dia sebaik-baik pelindung".

\section{SIMPULAN}

Berdasarkan Teori Keagenan Islam, pentingnya untuk menjaga hubungan antara manusia dengan Allah maupun manusia dengan manusia. Oleh karena itu, dalam konteks pengelolaan entitas syariah seperti bank syariah, DPS merupakan wakil DSN MUI dan juga bagian dari entitas syariah yang diharapkan mampu menjadi jembatan antara entitas syariah dengan stakeholdernya. Lebih jauh lagi, DPS juga diharapkan untuk mendekatkan bank syariah dengan keridhaan Allah SWT melalui proses pengawasan syariah agar bank syariah selalu terjaga dalam menjalan aktivitasnya.

Dalam rangka menjaga independensinya, DPS mengalami beberapa tantangan seperti posisi DPS yang menjadi bagian dari pengurus bank syariah, mendapat persetujuan dari RUPS setelah diajukan oleh direksi dan atau dewan komisaris serta adanya potensi menjadi anggota DSN MUI. Namun demikian, DPS diharapkan tetap mampu menjaga independensinya dalam menjalankan tugas dan bebas dari intervensi dari pihak-pihak yang memiliki conflict of interest. Hal lain yang mungkin berpotensi untuk mereduksi independensi DPS adalah diperbolehkannya jabatan rangkap di LKS lain dengan pertimbangan keterbatasan jumlah DPS yang kompeten.

Dengan adanya tantangan dalam menjaga independensi bank syariah tersebut, maka beberapa hal berikut dapat dipertimbangkan oleh regulator: pertama, perlu adanya kode etik bagi DPS dalam menjalankan peran dan fungsinya; kedua, DSN MUI dapat bekerja sama dengan perguruan tinggi yang memiliki program studi ekonomi Islam dan atau keuangan syariah untuk menyelenggarakan pendidikan khusus bagi calon-calon DPS sehingga jumlah DPS bisa semakin banyak. Harapannya bahwa dengan posisi ideal dimana DPS dapat membatasi rangkap jabatan dan meningkatkan profesionalitasnya. Tentu saja hal ini perlu dibarengi dengan kompensasi yang layak bagi DPS apalagi jika ke depan profesi DPS dilaksanakan oleh personil yang fulltime 
pekerjaannya. Ketiga, perlu diinisiasi adanya Kantor Audit Syariah (KAS) yang posisinya di luar LKS seperti halnya Kantor Akuntan Publik (KAP) yang fokus pada pemeriksaan aspek keuangan yang sesuai dengan SAP. Keempat, perlu dirumuskan standar audit syariah yang lebih professional untuk menjamin kualitas pemeriksaan aspek syariah.

\section{Daftar Pustaka}

AAOIFI. (2017). Audit, Assurance, and Ethics (AAE). Manama: AAOIFI.

Abdel Karim, R. A. (1990). The Independence of Religious and External Auditors: The Case of Islamic Banks. Accounting, Auditing \& Accountability Journal, (Vol. 3, Issue 3, pp. 34-44). https://doi.org/10.1108/09513579010004097

Anggraeni, M. D. (2011). Agency Theory dalam Perspektif Islam. Jurnal Hukum Islam, STAIN Pekalongan. 9(2), 1-13.

Bank Muamalat Indonesia. (2019). Laporan Tahunan Bank Muamalat Indonesia (BMI). Jakarta : BMI

Fauzi, A., \& Supandi, A. F. (2019). Perkembangan Audit Syariah Di Indonesia. Jurnal Istiqro, 5(1), 24. https://doi.org/10.30739/istiqro.v5i1.339

Khalid, A. A., \& Sarea, A. M. (2020). Independence and effectiveness in internal Shariah audit with insights drawn from Islamic agency theory. International Journal of Law and Management. https://doi.org/10.1108/IJLMA-02-2020-0056

Khotibul, U. (2015). Urgensi Standarisasi Dewan Pengawas Syariah dalam Meningkatkan Kualitas Audit Kepatuhan Syariah.Jurnal Perhimpunan Mahasiswa Hukum Indonesia Cabang Daerah Istimewa Yogyakarta, 1(2), 114-138.

Misbach, I. (2015). Kedudukan dan Fungsi Dewan Pengawas Syariah dalam Mengawasi Transaksi Lembaga Keuangan Syariah di Indonesia. Jurnal Minds: Manajemen Dan Inspirasi, 3(1), 79-93. http://library1.nida.ac.th/termpaper6/ sd/2554/19755.pdf

Munthe, A. K., Praramadhani, I. S., \& Satrya, R. I. (2019). Peran Dewan Pengawas Syariah Dalam Pemenuhan Shariah Compliance Oleh Lembaga Keuangan Syariah. Sharia Journal Of Islamic Law Studies, 2(3).

Nurhisam, L. (2016). Kepatuhan Syariah (Sharia Compliance) dalam Industri Keuangan Syariah. Jurnal Hukum IUS QUIA IUSTUM, 23(1), 77-96. https://doi. org/10.20885/iustum.vol23.iss1.art5 
Perwataatmadja, K., \& Antonio, M. S. (1992). Apa dan Bagaimana Bank Islam. Jakarta: Dana Bhakti Wakaf.

Prasetyoningrum, A. (2010). Analisis Pengaruh Independensi dan Profesionalisme Dewan Pengawas Syariah terhadap Kinerja Bank Perkreditan Rakyat Syariah di Jawa Tengah. Jurnal Ilmu Ekonomi ASET, 12(1), 75-86.

Shamsuddin, Z., \& Ismail, A. G. (2013). Agency theory in explaining Islamic financial contracts. Middle East Journal of Scientific Research, 15(4), 530-545. https:// doi.org/10.5829/idosi.mejsr.2013.15.4.2361

Wardayati, S. M. (2011). Implikasi Shariah Governance Terhadap Reputasi Dan Kepercayaan Bank Syariah. Walisongo: Jurnal Penelitian Sosial Keagamaan, 19(1), 1. https://doi.org/10.21580/ws.2011.19.1.210

www.mui.or.id

www.dsnmui.or.id 